\title{
Determination of Efficient Superfinishing Conditions for Mirror Surface Finishing of Engineering Ceramics
}

\author{
Sang-Kyu Kim*, Young-Tae Cho**, Yoon-Gyo Jung \# \\ ( *,**, \# Department of Mechanical Engineering, Changwon National Univ., ) \\ 엔지니어링 세라믹스의 경면연마를 위한 효율적인 \\ 슈퍼피니싱 조건의 결정 \\ 김상규 ${ }^{*}$, 조영태 ${ }^{* *}$, 정윤교 ${ }^{*}$
}

(Received 14 August 2014; received in revised form 24 October 2014; accepted 27 October 2014)

\begin{abstract}
The Engineering ceramics have some excellent properties as materials for modern mechanical and electrical components. It is, however, not easy to polish them efficiently because they are strong and hard. This study is carried out to obtain a mirror surface on engineering ceramics by surperfinishing with high efficiency. To achieve this, we conducted a series of polishing experiments using representative engineering ceramics, such as $\mathrm{Al}_{2} \mathrm{O}_{3}, \mathrm{SiC}, \mathrm{Si}_{3} \mathrm{~N}_{4}$ and $\mathrm{ZrO}_{2}$, using diamond abrasive film from the perspective of oscillations peed, the rotational speed of the workpiece, contact roller hardness, contact pressure and feed rate. Furthermore, the polishing efficiency and characteristics for engineering ceramics are discussed on the basis of optimal polishing time and surface roughness. Our results confirmed that efficient superfinishing conditions and polishing characteristics o $f$ engineering ceramics can be determined.
\end{abstract}

Key Words : Superfinishing(슈퍼피니싱), Diamond Lapping Film(다이아몬드 랩핑 필름), Engineering ceramics (엔지니어링 세라믹스), Optimal polishing time(최적연마시간), Mirror surface finishing(경면연마)

\section{Introduction}

Engineering ceramics have excellent characteristics, such as high hardness, wear resistance and a typically

\footnotetext{
* Department of Mechanical Engineering, Changwon national University

** Department of Mechanical Engineering, Changwon national University

\# C. A. : Department of Mechanical Engineering, Changwon national University

E-mail : ygjung@changwon.ac.kr
}

insulating nature, and are suited for a wide variety of functions. They are often used for high-temperature parts because of their ability to maintain strength and stiffness at high-temperature. In particular, they are chosen as materials for ball bearings and automated machine parts because of their outstanding wear resistance. In the field of precision parts, it is important to select the proper polishing conditions and to use a polishing system that can improve surface roughness to satisfy various conditions, such as airtightness, and to limit the damage caused by the friction 
of sliding parts. This is in line with the greatly increasing demand for mirror surface finishing and precision machining. ${ }^{[1-5]}$ Consequently, polishing systems for ultra-precision machining require a high level of technology as well as considerable investment in equipment. In addition, it is difficult to automate a polishing process due to factors that include poor working environments, insufficient technical materials, and non-uniform polishing products. Therefore, the polishing process depends heavily on the experience of skilled workers.

Recently, there have been several research studies concerning mirror surface finishing and efficient superfinishing using abrasive film based on metallic materials like $\mathrm{SM} 45 \mathrm{C}^{[6]}$, but there has been no case study on the superfinishing of engineering ceramics; thus, the need for such a study has become conspicuous. The purpose of this work is to determine mirror surface finishing conditions and efficient and economical superfinishing conditions for the superfinishing of engineering ceramics using an abrasive film under varying conditions. These conditions include the workpiece rotation speed, the oscillation speed, the contact pressure of the roller, the hardness of the roller, and the type of abrasive film.

\section{Experimental device and experimental method}

In this study, experiments were carried out with the same products and experimental equipment used for a previous study.$^{[7]}$ The $\mathrm{T}_{\mathrm{opt}}$ and $\mathrm{R}_{\mathrm{af}}$ values were also selected in the same way. We carried out a series of experiments to determine the superfinishing conditions for an efficient mirror surface using. The materials used for the experiment were the most common engineering ceramics, $\mathrm{Al}_{2} \mathrm{O}_{3}$, $\mathrm{ZrO}_{2}, \mathrm{SiC}$ and $\mathrm{Si}_{3} \mathrm{~N}_{4}$. Their mechanical properties are shown in Table 1. For the abrasive film, Diamond Lapping Film(DLF) was used, and an
SEM image of the particle size of each abrasive film is shown in Fig.1. The surface roughness of apolished work piece was measured using a stylus type surface roughness measuring in strument (Kosaka Laboratory Ltd., Korea). Table 2 gives the superfinishing conditions in the experiment.

Table 1 Mechanical properties of engineering ceramics

\begin{tabular}{crccc}
\hline & $\begin{array}{l}\text { Density } \\
\left(\mathrm{g} / \mathrm{cm}^{3}\right)\end{array}$ & $\begin{array}{c}\text { Hardness } \\
\left(\mathrm{Kg} / \mathrm{mm}^{2}\right)\end{array}$ & $\begin{array}{l}\text { Fracture } \\
\text { Toughness } \\
\left(\mathrm{Kg} / \mathrm{mm}^{2}\right)\end{array}$ & $\begin{array}{l}\text { Young's } \\
\text { Modulus } \\
(\mathrm{GPa})\end{array}$ \\
\hline \hline $\mathrm{Al}_{2} \mathrm{O}_{3}$ & 3.9 & 1800 & 26 & 350 \\
$\mathrm{ZrO}_{2}$ & 3.8 & 1250 & 50 & 210 \\
$\mathrm{SiC}$ & 3.5 & 2700 & 20 & 420 \\
$\mathrm{Sl}_{3} \mathrm{~N}_{4}$ & 3.5 & 1500 & 33 & 240 \\
\hline
\end{tabular}

Table 2 Experimental conditions

\begin{tabular}{ll}
\hline \multicolumn{1}{c}{ Items } & \multicolumn{1}{c}{ Conditions } \\
\hline Oscillation speed $\left(\mathrm{V}_{\mathrm{o}}\right)$ & $\begin{array}{l}100,400,700,1000 \\
(\mathrm{rpm})\end{array}$ \\
$\begin{array}{l}\text { Workpiece rotation speed } \\
\left(\mathrm{V}_{\mathrm{w}}\right)\end{array}$ & $\begin{array}{l}100,400,700,1000 \\
(\mathrm{rpm})\end{array}$ \\
Contact pressure $\left(\mathrm{P}_{\mathrm{a}}\right)$ & $1,2,3\left(\mathrm{kgf} / \mathrm{cm}^{2}\right)$ \\
Contact roller hardness $\left(\mathrm{R}_{\mathrm{h}}\right)$ & $50,70,90(\mathrm{Hs})$ \\
& $\begin{array}{l}\mathrm{Al}_{2} \mathrm{O}_{3}, \mathrm{ZrO}, \mathrm{SiC} \\
\mathrm{Si}_{3} \mathrm{~N}_{4}\end{array}$ \\
Workpiece & $\mathrm{Diamond} \mathrm{Lapping}$ \\
Kind of film & Film (DLF) \\
Kind of abrasive & $6,9,15 \mu \mathrm{m}$ \\
Grain size &
\end{tabular}




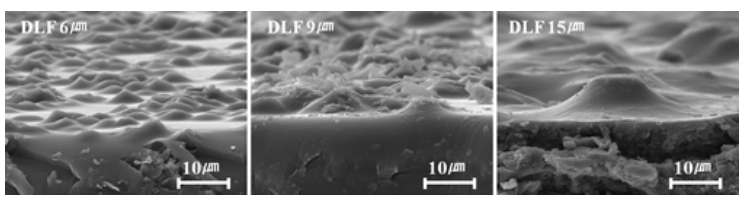

Fig. 1 SEM micrographs of abrasive films

\section{Efficient superfinishing conditions}

This section reviews the experiment that investigates the effects of the most basic abrasion conditions, namely the workpiece rotation speed $V_{w}$ and oscillation speed $V_{o}$ change, on the optimal abrasive hours $T_{o p}$ and final surface roughness $\mathrm{Ra}_{\mathrm{f}}$ of the engineering ceramics.

Fig. 2 shows the change of $\mathrm{T}_{\mathrm{opt}}$ and $\mathrm{Ra}_{\mathrm{f}}$ values
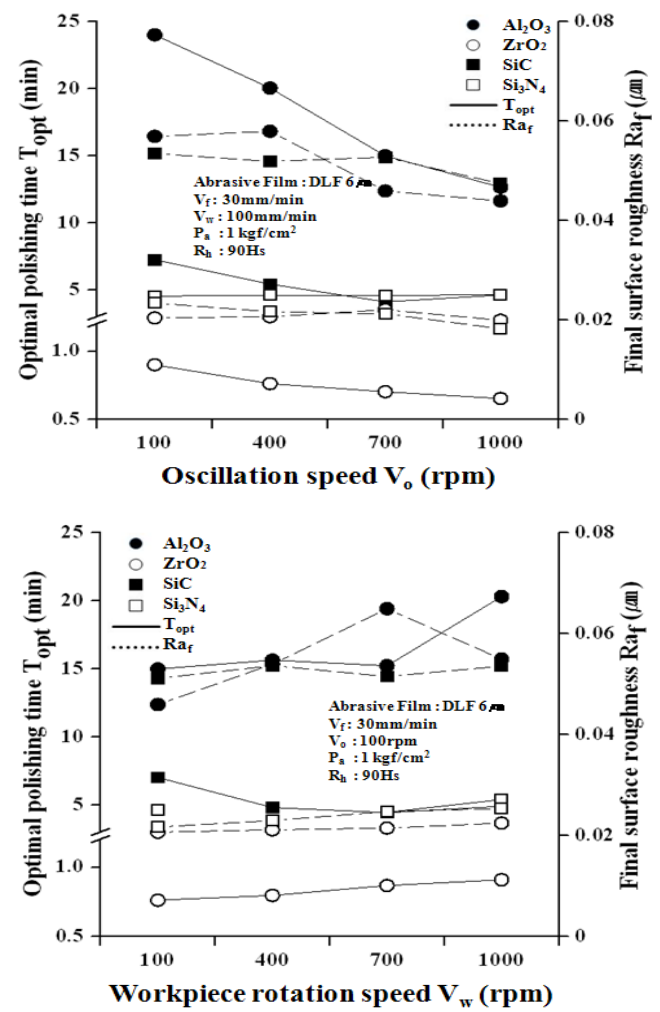

Fig. 2 Behavior of optimal polishing time and final surface roughness according to the $V_{0}$ and $\mathbf{V}_{\mathrm{w}}$ with increasing $V_{o}$ and $V_{w}$. As shown in the figure, $T_{\text {opt }}$ and $\mathrm{Ra}_{\mathrm{f}}$ values decreased due to an increase in the amount of abrasion per unit of time following an increase of $\mathrm{V}_{\mathrm{o}}$. The same phenomena and aspects were observed with superfinishing SM45C and SUS304 as the metallic materials. On the other hand, as $V_{w}$ increased, $T_{\text {opt }}$ and $\mathrm{Ra}_{\mathrm{f}}$ values also increased, so it is likely that an increased amount of diamond was eliminated from the backing film with softer resin, due to the high hardness of the engineering ceramics. Therefore, for efficiently superfinishing engineering ceramics, the $V_{0}$ value should be increased and the $\mathrm{V}_{\mathrm{w}}$ value should be decreased.
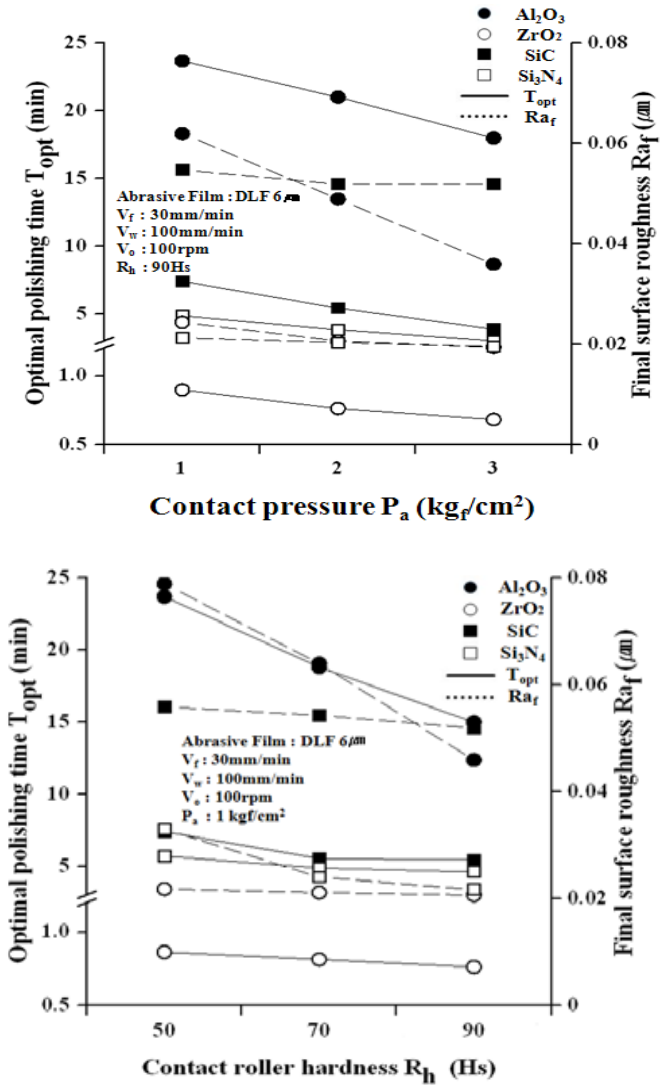

Fig. 3 Behavior of optimal polishing time and final surface roughness according to the $P_{a}$ and $\mathbf{R}_{h}$ 
The contact pressure and contact roller hardness are important factors affecting the interference surface between the abrasive grain and material for abrasion. Fig. 3 shows the change of $T_{\text {opt }}$ and $R_{a f}$ with increasing $P_{a}$ and $R_{h}$. As the value of $P_{a}$ and $\mathrm{R}_{\mathrm{h}}$ increases, $\mathrm{T}_{\mathrm{opt}}$ and $\mathrm{R}_{\mathrm{af}}$ improve. For roller hardness, a higher hardness badly affects a material with a relatively lower hardness like aluminum ${ }^{[8]}$, but it has a positive impact on the abrasion surface for a material with high hardness like engineering ceramics because of particle shredding. Fig. 4 shows $1000 \times$ magnification pictures taken with a scanning electron microscope of a film surface by the change of contact pressure. As the roller contact pressure value increased as in Fig. 4, the interference surface between the abrasive grain and material increased, which confirmed that the abrasive surface can be improved efficiently.

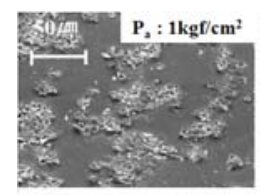

Workpiece : $\mathrm{A12O3}$

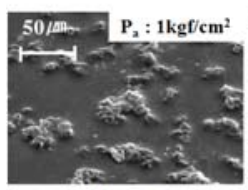

Workpiece : Si3N4

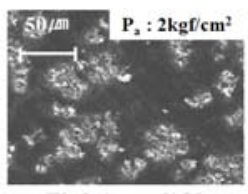

Workpiece : $\mathrm{A12O}$

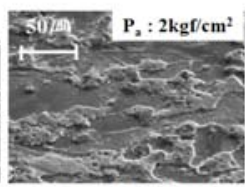

Workpiece : $\mathrm{Si} 3 \mathrm{~N} 4$

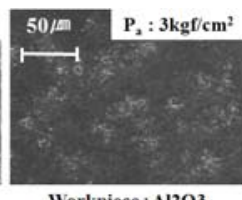

Workpiece : $\mathrm{Al2O}^{2}$

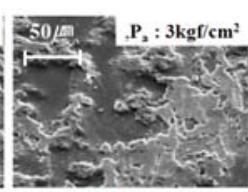

Workpiece : Si3N4
Fig. 4 SEM photograph of diamond lapping film

\section{Determination of mirror surface finishing conditions}

Engineering ceramics are generally polished with DLF because they are brittle materials that have high strength and hardness. DLF30, DLF15, DLF09 and DLF06 is used for the superfinishing of engineering ceramics on the site, and it is 10 times more expensive than the polishing film of $\mathrm{Al}_{2} \mathrm{O}_{3}$ and $\mathrm{SiC}$ particles. Accordingly, the waste of polishing film due to inefficient polishing causes an increase in the product cost. Here we describe an experiment in the efficient applicable combination of polishing films so as to obtain the mirror-like surface $(\operatorname{Ra} 0.02 \mu \mathrm{m})$ of engineering ceramics with the above four kinds of polishing film.

In order to determine the combination method of the polishing film, we measured the final roughness according to the polishing time for the polishing film DLF6, DLF9 and DLF15, as shown in Fig. 5, Fig. 6.

Generally, as particle size was smaller with a lower obtained roughness. We verified that we could not obtain a final roughness $\mathrm{Ra}$ of less than $0.02 \mu$ $\mathrm{m}$ with the polishing film of DLF9 and DLF15. Therefore, we carried out the final polishing with
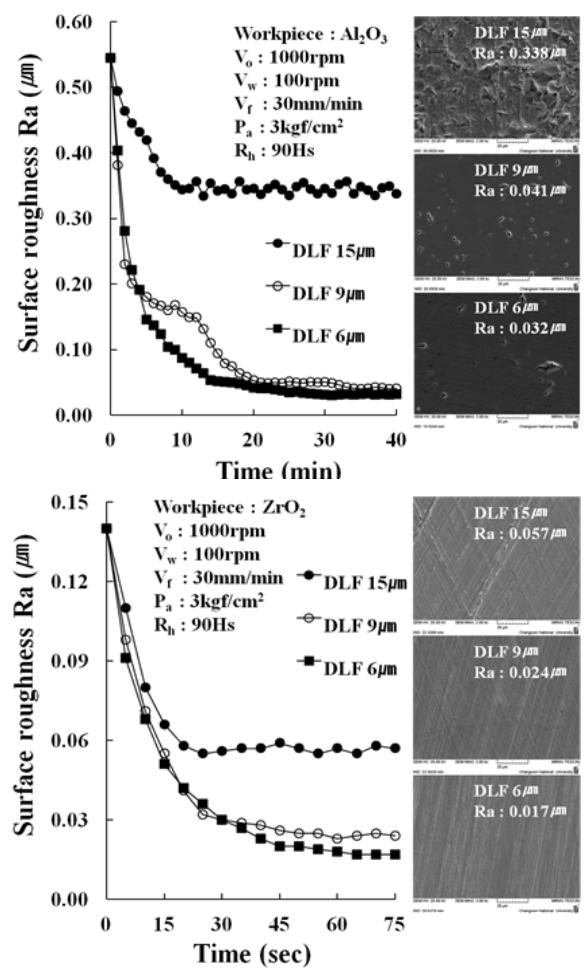

Fig. 5 Behavior of optimal surface roughness according to the polishing time with a change in grain size $\left(\mathrm{Al}_{2} \mathrm{O}_{3}, \mathrm{ZrO}_{2}\right)$ 


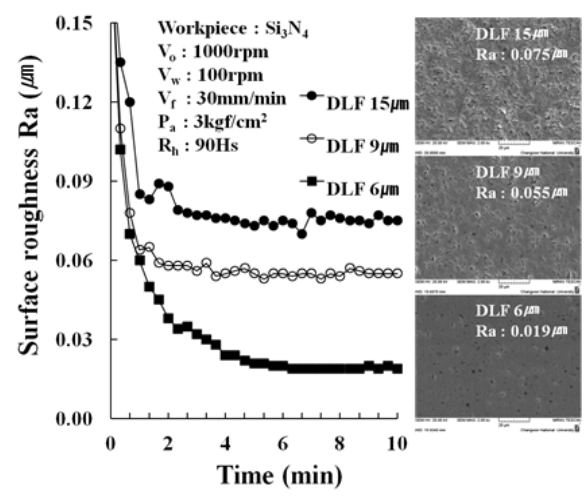

Table 3 Determination of polishing film application combinations

\begin{tabular}{|c|c|c|c|c|}
\hline App. Comb & $\begin{array}{c}\text { DLF } \\
30\end{array}$ & $\begin{array}{c}\text { DLF } \\
15\end{array}$ & $\begin{array}{c}\text { DLF } \\
09\end{array}$ & $\begin{array}{c}\text { DLF } \\
06\end{array}$ \\
\hline DML 01 & 0 & 0 & 0 & 0 \\
\hline DML 02 & 0 & O & $x$ & 0 \\
\hline DML 03 & 0 & $x$ & 0 & 0 \\
\hline DML 04 & O & $x$ & $x$ & $\bigcirc$ \\
\hline
\end{tabular}

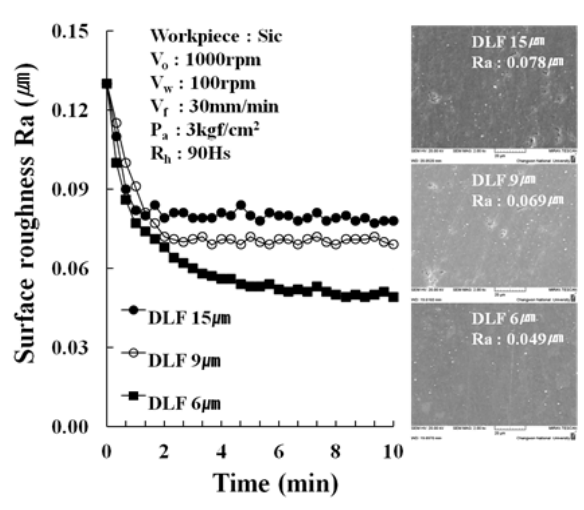

Fig. 6 Behavior of optimal surface roughness according to the polishing time with a change in grain size $\left(\mathrm{Si}_{3} \mathrm{~N}_{4}, \mathrm{SiC}\right)$

DLF6. In order to maintain consistency in the experiment, the surface to be polished was initialized with DLF30. Table 3 shows applicable combinations of polishing films of the four kinds.

Fig. 7 shows the diagram results of experimentally obtaining $T_{t}$ of the applicable combination of DML 01 for $\mathrm{Al}_{2} \mathrm{O}_{3}$ ceramics. As shown in the figure, the roughness in initializing the surface to be polished, with DLF30, is $0.56 \mu \mathrm{m}$. At this point, for being polished with DLF15, the already measured $\mathrm{T}_{\text {opt }}$ is $3.8 \mathrm{~min}$.

Accordingly, with a polishing time of $3.8 \mathrm{~min}$, DLF9 is substituted, and then it is polished to $T_{\text {opt }}$ (already measured value $10 \mathrm{~min}$ ), DLF6 is substituted

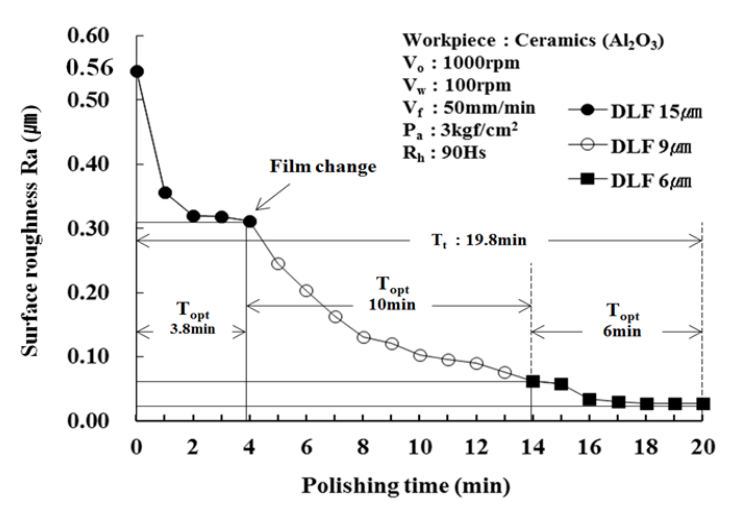

Fig. 7 Behavior of surface roughness according to polishing time by DML01 combination

Table 4 Comparison of final surface roughness and total polishing for various polishing film application combinations

\begin{tabular}{|l|c|c|c|c|c|c|c|c|}
\hline \multirow{2}{*}{ Comat. } & \multicolumn{2}{|c|}{$\mathrm{Al}_{2} \mathrm{O}_{3}$} & \multicolumn{2}{c|}{$\mathrm{ZrO}_{2}$} & \multicolumn{2}{c|}{$\mathrm{Si}_{3} \mathrm{~N}_{4}$} & \multicolumn{2}{c|}{$\mathrm{SiC}$} \\
\cline { 2 - 10 } & $\mathrm{R}_{\mathrm{af}}$ & $\mathrm{T}_{\mathrm{t}}$ & $\mathrm{R}_{\mathrm{af}}$ & $\mathrm{T}_{\mathrm{t}}$ & $\mathrm{R}_{\mathrm{af}}$ & $\mathrm{T}_{\mathrm{t}}$ & $\mathrm{R}_{\mathrm{af}}$ & $\mathrm{T}_{\mathrm{t}}$ \\
\hline DML01 & 0.026 & 1180 & 0.013 & 33 & 0.018 & 105 & 0.048 & 116 \\
\hline DML02 & 0.027 & 1248 & 0.014 & 43 & 0.017 & 114 & 0.047 & 110 \\
\hline DML03 & 0.027 & 1068 & 0.013 & 32 & 0.018 & 108 & 0.047 & 130 \\
\hline DML04 & 0.026 & 780 & 0.014 & 39 & 0.017 & 102 & 0.047 & 125 \\
\hline \multicolumn{19}{|c}{} & \multicolumn{6}{c}{ (Unit : $\mu \mathrm{m}, \mathrm{sec})$} \\
\hline
\end{tabular}

again, and then it is polished to $T_{\text {opt }}$, and then the process ends. This results in a $T_{t}$ value of $19.8 \mathrm{~min}$. Table 4 shows the comparison of final roughness $\mathrm{R}_{\mathrm{af}}$ and total polishing time $\mathrm{T}_{\mathrm{t}}$ for $\mathrm{Al}_{2} \mathrm{O}_{3}, \mathrm{SiC}, \mathrm{Si}_{3} \mathrm{~N}_{4}$ and $\mathrm{ZrO}_{2}$ ceramics by this method.

It can be said that the combination of DML04 is the recommended applicable combination of polishing films, 
when we consider $R_{a f}, T_{t}$, or time to substitute the polishing film, and so forth according to each material, as shown in the table.

\section{Conclusion}

We conducted an experimental study to determine efficient superfinishing conditions and an efficient applicable combination of polishing films for mirror surface machining from the viewpoint of the rotation speed of the workpiece, the oscillation speed, the contact pressure of the roller, the hardness of the roller, the kind of polishing film, etc. for carrying out the super-finishing of engineering ceramics using the polishing films in this study We came to the following conclusions.

1. For efficient conditions for superfinishing engineering ceramics, the oscillation speed $\left(\mathrm{V}_{\mathrm{o}}\right)$ and the contact pressure $\left(\mathrm{P}_{\mathrm{a}}\right)$ should be $3 \mathrm{kgf} / \mathrm{cm}^{2}$, the contact roller hardness $\left(\mathrm{R}_{\mathrm{h}}\right)$ should be $90 \mathrm{Hs}$, and the workpiece rotation speed $\left(\mathrm{V}_{\mathrm{w}}\right)$ value should be decreased for set-out.

2. For the recommended applicable combination of polishing films for mirror-like polishing of ceramics, it is efficient to polish ceramics with only DLF04 to the end if we consider $R_{a f}$, $T_{t}$, or time to substitute for the polishing film.

\section{References}

(1) Shin, O. C., Jung, S. R. and Jung, Y. G., "Development of internal superfinishing system use abrasive film", Transactions of the Korea Society of Machine Tool Engineers, Vol.2007, pp. 154-159, 2007.

(2) Jung, S. Y., Shin, O. C. and Jung, Y. G., "A Study on the Practical Application Conditions of Polishing Film for High-Efficiency Superfinishing" , Spring Conference of KSMPE, pp. 115-121, 2008.

(3) K. Susuki, "Development of New Mechanochem -ical Polishing Method with a Polishing Film for Ceramic Round Bars", Annals of the CIRP, Vol. 41, No. 1, pp. 339-342, 1972

(4) Chang, S. H., Thomas, N. Farris. and Srinivasan Chandrasekar., "Contact Mechanics of Superfinishi -ng", The Association for the Study of Medical Education, Vol. 122, No. 2, pp. 388-393, 1999.

(5) Yoshiharu Namba, Hideo Tsuwa, "Wear Process of Abrasive Belt-Studies on the Belt Grinding(3rd Report)", Japan Society of Precision Engineering, Vol. 38, No. 2, pp. 202-208, 1972.

(6) Kim, H. B., Kim, K. S. and Namgung, S., "A Study on the Mirror Surface Finishing of SM45C using Micro Abrasive Film", Journal of Central South University of Technology, Journal of the Korean Institute of Industrial Educators, Vol. 22, No. 1, pp. 190-198, 1997.

(7) Kim, J. S., Lim, E. S. and Jung, Y. G., "Determination of efficient superfinishing conditions for mirror surface finishing of titanium", Journal of Central South University of Technology, Vol. 19 No. 2, pp. 155-162, 2012.

(8) Jung, S. Y., Park, K. B. and Jung, Y. G., "An experimental study on the determination of efficient superfinishing conditions using polishing film", The Korean Society for Precision Engineering, Vol. 26 No. 8, pp. 55-61, 2009. 